A very successful symposium on the subject of earthquakes was held recently in Melbourne under the auspices of the Structural Branch of the Institution of Engineers Australia (Victoria Division) and the Geophysics Group of the Australian Institute of Physics.

The Savoy Plaza provided convenient conference facilities for well over one hundred delegates from public bodies, universities, major industries and consulting engineers from Australia, Papua - New Guinea and New Zealand together with three special guest speakers from U.S.A. A regrettable feature was the apparent lack of interest on the part of the architects.

The program (set out at the end of this note) opened with papers summarising the considerable volume of records of earthquake activity in many parts of Australia and in Papua - New Guinea. The latter has seismicity comparable with that of New Zealand and there is already a substantial body of Australian engineers and scientists strongly interested and increasingly experienced in earthquake design. In Australia itself with 18 known earthquakes of substantial size in less than one hundred years and with several of the known regions of seismic activity embracing important cities, the case was strongly presented that seismic risks could no longer be ignored. It was suggested that in the absence of long periods of observation the study of microtremors on which considerable work has been done could give useful indication of seismicity of a locality in a matter of a few years.

The program continued with papers on engineering design for earthquake conditions and these included two from New Zealand. These were followed by the guest speakers from the U.S.A.:-

Mr M. Fintel (Director of the Engineering Design and Standards Department, Portland Cement Association, Illinois,) reviewed the fundamentals of earthquake resistant design in reinforced concrete and described recent elaboration of code requirements which ensure ductile performance in concrete structures. He mentioned that the Uniform Building Code required higher seismic factors for braced structures and higher still for structures "other than buildings".

He suggested that until more is known of Australian levels of seismicity, building codes at least for the known regions of higher seismicity should have definite even if limited ductility requirements.

* Research Engineer N.Z. Electricity Department, Wellington. 
As Guest Speaker at the Symposium Dinner Mr Fintel described the effects of the Caracas earthquake to illustrate that seismic loading allowed in design may be nullified - disastrously - if nominally "non structural" components are allowed to interfere with the proper development of ductility in the finished building.

Mr O. E. Stevenson, (Chief Structural Engineer American Iron and Steel Institute New York) reviewed research projects sponsored by the Institute particularly energy absorbtion in structures with cyclic loading beyond yield point and the extension of this work into braced structures.

Prof. B.A. Bolt, (Professor of Seismology, University of California Berkeley) reviewed developments in earthquake research in the U.S. He indicated that when development and expansion in a country is the overriding spirit, there is often resistance to publicity and research on earthquake hazards but when intensified urban development augments potential disaster, the concern felt by specialists can be reflected in public opinion through the activities of professional bodies such as Seismological Societies and Earthquake Research Institutes (especially when aided by some actual earthquake experience). A National Committee for Earthquake Engineering in Australia (aided by the Meckering earthquake) could serve such a role.

Professor Bolts present position as Visiting Professor, Department of Applied Mathematics, University of Sydney is one indication of the scale and vigour with which Australian Engineers and Scientists are tackling their earthquake problems.

A film on the Alaskan earthquake (loaned by the N.Z. Civil Defence Organisation) which included shots taken during the actual shaking, provided a dramatic conclusion to the discussions and a preparation for the final items of business - the proposal to establish a National Committee for Earthquake Engineering for Australia.

The proposal was warmly supported and the following officers were elected:-

Chairman: Prof. F.S. Shaw, Department of Structural Mechanics, School of Civil Engineering, University of N.S.W.

Vice-Chairman: Dr. D.J. Sutton, Department of Physics, University of Adelaide.

Secretary: Mr H.A. Knox, Standards Association of Australia.

List of Papers Presented:

Earthquake Intensities in Australia - H. Doyle, Australian National University, Canberra.

The National Seismic Coverage - J.A. Brooke. Bureau of Mineral Resources, Canberra.

Recent Damaging Earthquakes in New Guinea - Dr. D. Denham, Geophysical Observatory, Port Moresby. 
Numerical Seismic Risk - R. Underwood, U.K. Atomic Energy Commission. Meckering Earthquake Intensities and Notes On Earthquake Risk for Western Australia - I.B. Everingham, Mundaring 'Geophysical Observatory, Western Australia.

The Effect on Buildings of the Meckering Earthquake (October 1968) F.D. Beresford, C.S.I.R.O., Melbourne.

Seismicity of Tasmania - Dr. W.D. Parkinson, University of Tasmania. Acceleration, Magnitude and Frequency Variations of South Australian Earthquakes - Dr. D.J. Sutton, University of Adelaide.

Earthquake Engineering Design Philosophy - Dr. G.R. Walker, University College of Townsville.

Comparison of Seismic Design Codes -C.T.J.Bubb and J. Lloyd, Commonwealth Dept. Works, Melbourne.

Structural Engineering for Earthquake Conditions in N.Z. - N. Rowley, Brickell, Moss, Rankine and Hill, N.Z.

The Seismic Design of Bridges - R. Shepherd, University of Canterbury. N.Z.

Foundation Stability under Earthquake Loading - P. McGregor, Electricity Commission, N.S.W.

Earthquake Design of Reinforced Concrete Chimneys - A. Fellows, Tileman A/asia Pty. Ltd.

Earthquake Engineering related to Reinforced Concrete Structures M. Fintel, Director Engineering Design and Standards Dept., Portland Cement Association. U.S.A.

Earthquake Engineering Research and Steel Structures - E.O. Stephenson, American Iron and Steel Institute.

Some Aspects of Earthquake Research in the U.S. - Prof. B.A. Bolt, University of California, Berkeley.

The Use of Microtremors in Evaluation Earthquake Activity - Prof. R. Green, University of New England, Armidale

A Storage and Retrieval System of Seismic Data for the New Guinea Solomon Islands Region - Dr. D. Denham and Mrs W.M.J. Byrne, Geophysical Observatory, Port Moresby, Papua.

Does Australia have an Earthquake Problem? - Prof. F.S. Shaw, University of New South Wales. 
Sets of the above papers are still available (price \$10) from:

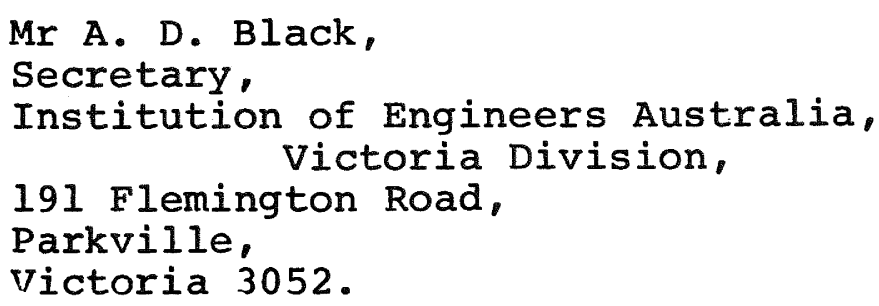

\section{Future Issues}

The next issue of the Bulletin will be that of March 1970. It is hoped to include a paper upon study of earth deformation in California, and information of procedures of the Federal Government in disaster assistance in the United States of America.

The Society plans to organise a National Earthquake Engineering

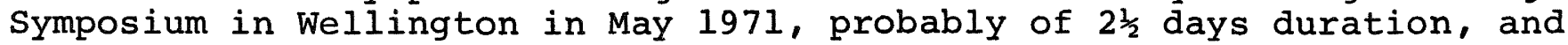
agreement in principal to sponsor this event has been given by the Council of the New Zealand Institution of Engineers. Further information will be available, it is reported, early in 1970. Information will be included in future issues of this Bulletin.

The Editor is seeking contributions of papers for the issues of June and september 1970, for which the closing dates for the receipt of manuscripts in Wellington are April 15 and July 15 respectively. In particular, papers from architect colleagues would be welcome, and notes of inquiry, comment or criticism from designers generally to stimulate the Code Feature Section. 